\title{
PERBAIKAN PENGELOLAAN USAHA KERAJINAN TENUN NAGARI KUBANG KABUPATEN LIMA PULUH KOTA
}

\author{
Darnetti ${ }^{1)}$, Nelson Elita ${ }^{2)}$ dan Harmailis ${ }^{3)}$ \\ ${ }^{1}$ Program Studi Pengelolaan Agribisnis Pertanian, Politeknik Pertanian Negeri Payakumbuh \\ ${ }^{2}$ Program Studi Budidaya Tanaman Pangan, Politeknik Pertanian Negeri Payakumbuh \\ ${ }^{3}$ Program Studi Tata Air Pertanian, Politeknik Pertanian Negeri Payakumbuh \\ email: darnetti62@yahoo.com; nelsonelita@yahoo.com; harmailis_chaniago@yahoo.com
}

\begin{abstract}
ABSTRAK
Menenun sudah dilakukan sejak dulu kala untuk kebutuhan sandang manusia. Orang Minangkabau menyebut diri mereka sebagai orang beradat, kain tenun tidak bisa dipisahkan dari upacara-upacara adat istiadat.Kain tenun ditinjau dari bahan, cara pembuatan, dan harganya, menunjukkan kemuliaan derajat dan martabat pemakainya. Kondisi ini menjadikan kerajinan tenun sebagai salah satu industri rumah tangga dan memunculkan kelompok usaha kecil dan menengah (UKM) di kalangan masyarakat khususnya di Nagari Kubang Kabupaten Limapuluh Kota. Kelompok usaha kecil dan menengah (UKM) Marni Geneng dan CV Rangkiang adalah mitra dari IbPE Kerajinan Tenun Minangkabau di Nagari Kubang Kabupaten Limapuluh Kota. Kedua UKM ini sepakat untuk bermitra dalam kegiatan IbPE yang diselenggarakan oleh Tim Pengabdian Politeknik Pertanian Negeri Payakumbuh dalam rangka menuju pasar ekspor luar negeri. Tujuan dalam program IbPE pada kedua UKM ini adalah memperbaiki pengelolaan usaha berupa perbaikan administrasi, jumlah dan mutu produk serta promosi untuk memperluas pasar produk. Hasil yang dicapai dalam program IbPE tahun I ini adalah perbaikan adminsitrasi pengelolaan UKM berupa penataan buku kas, buku stok, buku penjualan, buku pembelian, buku tamu tersedia dengan rapi. Pelatihan pewarna alami menghasilkan produk tenun yang berwarna natural. Pelatihan pengembangan motif meningkatkan kualitas produk tenun yang dihasilkan lebih menarik. Pemasangan arah penunjukan jalan pada kedua UKM sehingga lokasi UKM mudah ditemui konsumen. Pemberian kemasan pada produk kedua UKM meningkatkan nilai jual produk tenun UKM.
\end{abstract}

\section{Kata kunci : Kerajian Tenun, Marni Geneng, Rangkiang}

\section{PENDAHULUAN}

Pengertian tenun yakni proses pembuatan kain yang terbuat dari benang yang disebut lusing, benang tersebut dicelupkan ke pewarna terlebih dahulu sebelum akhirnya diikat atau dirajut secara selang seling menjadi sebuah helaian kain. Tenun juga dapat diartikan sebagai proses pembuatan kain yang dilakukan menggunakan mesin sederhana dan dibuat masih sangat tradisional yang banyak menggunakan tenaga manusia sebagai penggeraknya.

Arti tenun menurut kamus bahasa Indonesia adalah proses pembuatan sehelai kain dengan cara memasukkan benang pakan kedalam lusing. Sesuai dengan kebutuhan manusia atas bahan sandang aktivitas menenun mulai tersebar ke berbagai tempat di dunia. Penyebarannya merata meliputi benua Eropa, Amerika hingga ke Asia, dan akhirnya masuk ke wilayah Indonesia. Di Indonesia sendiri tenun juga mengalami penyebaran hingga ke pelosok daerah dan hampir disemua tempat memiliki produksi tenun yang unik dan berkualitas (Kartiwa, 1998). 
Menurut beberapa kolektur tenun dunia asal Amerika Serikat dan Kanada, Sumatera memiliki potensi besar untuk dapat menjadi daerah tujuan wisata kain tenun dunia. Hal ini didasarkan pada kekayaan motif tenun juga semata-mata produksi tenun yang terdapat di pulau tersebut. Didaerah Sumatera, beberapa tenun yang terkenal antara lain adalah tenun Pandai Sikek dan Silungkang dari Sumatera Barat, tenun songket Jambi, tenun Melayu, Toba dan Simalungun, Pakpak dari Sumatera Utara dan lain-lain.

Bagi orang Minangkabau yang menyebut diri mereka sebagai orang beradat, kain tenun adalah bagian yang tidak bisa dipisahkan dari upacara-upacara adat istiadat. Ditinjau dari bahan, cara pembuatan, dan harganya, menunjukkan kemuliaan derajat dan martabat pemakainya. Akan tetapi, kini bahan tenun seperti songket tidak hanya dimaksudkan untuk golongan masyarakat kaya dan berada semata, karena harganya yang bervariasi. Meskipun demikian, songket kualitas terbaik tetap dihargai sebagai bentuk kesenian yang anggun dan bernilai budaya tinggi.

Bahan tenun sudah banyak dimodifikasi tidak hanya dalam bentuk songket tetapi untuk bahan pakaian, sarung, tas, dompet dan sandal menjadi primadona sehingga sudah menjadi bagian dalam kebutuhan kehidupan oleh semua lapisan masyarakat. Kondisi ini menjadikan kerajinan tenun sebagai salah satu industri rumah tangga dan memunculkan kelompok usaha kecil dan menengah (UKM) dikalangan masyarakat khususnya Kabupaten Limapuluh Kota.

Dikabupaten Limapuluh Kota khususnya di Nagari Kubang sudah lama terkenal dengan Tenunan Kubang. Masyarakat didaerah ini menjadikan tenunan sebagai pekerjaan utama, berbagai bentuk hasil kerajian seperti kain songket, sarung, bahan pakain dengan berbagai motif mencirikan adat Minangkabau di produksi disini.

Kelompok Usaha Kecil Menengah Marni Geneng dan CV. Rangkiang adalah mitra dari IbPE Pengembangan Usaha Kerajinan Tenun Minangkabau Berpotensi Ekspor di Nagari Kubang Kabupaten Limapuluh Kota. Kedua UKM ini sepakat bermitra dalam kegiatan IbPE yang diselenggarakan oleh Tim Pengabdian Politeknik Pertanian Negeri Payakumbuh dalam rangka menuju pasar ekspor luar negeri.

Kelompok UKM Marni Geneng (selanjutnya disebut dengan UKM 1) berdomisili di Jalan Guci Nagari Kubang dengan jalan darat dari kampus Politeknik Pertanian Negeri Payakumbuh ke UKM 1 adalah $17 \mathrm{~km}$. Pimpinan dan sekaligus pemilik UKM 1 adalah Hj.Marni.

Kelompok UKM Rangkiang (selanjutnya disebut dengan UKM 2) berdomisili di jalan Bukit Panjang di Nagari Guguak Kabupaten Limapuluh Kota. Jarak tempuh dengan jalan darat dari kampus Politeknik Pertanian Negeri Payakumbuh ke UKM 2 adalah 20 km. Pimpinan dan sekaligus pemilik UKM 2 adalah Dewi Reni.

Pengerjaan proses pembuatan bahan tenun dari awal pendirian sampai sekarang yang dilakukan oleh UKM 1 adalah di rumah tempat tinggal pemilik UKM. Sudah mempunyai pemisahan ruangan yang khusus untuk pengerjaannya dan mempunyai pekerja sebanyak 10 orang penenun wanita dan 2 orang laki-laki tenaga pemintal benang. Total waktu yang dibutuhkan UKM mitra untuk memproduksi untuk bahan tenun pakaian yang bermotif songket 1 hari yang terdiri dari kain tenun dengan panjang 2 meter dan lebar 1,2 meter kadang 
lebih tergantung kerumitan motif dan menghasilkan satu stel songket adalah 15 hari sampai 1 bulan juga tergantung motif.

Pengerjaan proses pembuatan bahan tenun dari awal pendirian sampai sekarang yang dilakukan oleh UKM 2 adalah di rumah tempat tinggal pemilik UKM. Ada pemisahan ruangan yang khusus untuk pengerjaannya dan dikerjakan. Total waktu yang dibutuhkan UKM mitra untuk menghasilkan bahan pakaian tenun berupa baju kurung, baju gamis dan baju laki-laki bisa selesai 1 hari atau lebih tergantung pada motif dari bahan tenun, satu stel songket sekitar 1 bulan. Sekarang UKM 2 sudah mempunyai tenaga kerja penenun sebanyak 10 ditambah 1 orang pemintal benang semuanya wanita.

Kedua UKM ini masih tradsional dalam hal manajemen pembukuan, proses pertenuan dan motif masih kurang menarik, produksi masih sedikit, masih menggunakan benang dengan pewarna kimia, kurang promosi. Oleh karena itu perlu dilakukan pembinaan melalui program Hibah Ipteks bagi Produk Ekspor.

\section{METODE PELAKSANAAN}

Metode yang digunakan dalam program IbPE tahun I yaitu ceramah, diskusi, pendampingan pelatihan dan dan promosi.

\section{Ceramah, diskusi dan pendampingan.}

Ceramah dan diskusi diberikan untuk pemahaman kepada kedua UKM kelemahan dari kondisi yang ada dan perbaikan kedepan yang akan dikerjakan.

\section{Pelatihan.}

1. Diadakan pelatihan manajemen mengenai pembukuan arus kas, mencata uang kelaur dan uang masuk, pengarsipan.

2. Pelatihan pencelupan alami dengan bahan perwana dari alam

3. Pelatihan pengembangan motif.

\section{Promosi.}

Memberikan penunjuk arah untuk lokasi UKM dan memberikan kemasan untuk produk UKM

\section{HASIL DAN PEMBAHASAN}

\section{Ceramah, diskusi dan pendampingan}

Hasil ceramah, diskusi dan pendampingan kedua UKM mitra menyadari kelemahan yang dimiliki selama ini sehingga kedua UKM imi mau berbenah diri untuk memperbaki demi kemajuan usaha. Setiap kegiatan yang dilaksanakan dilakukan dulu ceramah apa yang akan dikerjakan tujuan dan manfaatnya kemudian didiskusikan kegiatan yang dilakukan. Selama kegiatan berlangsung tim IbPE selalu mendampingi kedua UKM mitra sehingga komunikasi antara UKM dan Tim IbPE selalu terjaga dalam melaksanakan kegiatan. 


\section{Pelatihan}

\section{Manajemen}

Di bidang manajemen yim IbPE memberikan workshop tentang akutansi, pembukuan, arsip, perencanaan produksi dan termasuk penghitungan pajak. Pelatihan tentang menghitung nilai investasi dan pelatihan laporan keuangan untuk memudahkan membuat aliran kas. Mitra

dimotivasi untuk mencatat dan mengarsipkan semua desain, motif dan produk yang dihasilkan sehingga dapat memelihara orisinal karya UKM mitra, yang pada akhirnya untuk perlindungan hak kekayaan intelektual (HKI). Hasil pelatihan/ workshop ini kedua UKM sudah mempunyai pembukuan yang rapi, perencanaan produksi dan arsip untuk kedepannya lebih tertata dan tercatat, UKM I dan UKM II mempunyai dokumentasi, arsip dan pembukuan yang rapi. Pemahaman pengusaha tenun dan anggota UKM I dan UKM II terhadap fungsi adminsitrasi dalam suatu usaha diperoleh hasil sangat memuaskan. Selanjutnya pemahaman terhadap pengisian adminitrasi berupa buku kunjungan, pesan dan saran dari kunjungan yang sangat berarti bagi perbaikan hasil tenun kedepannya diperoleh hasil sangat memuaskan. termasuk penghitungan pajak. Mitra didampingi untuk selalu mencatat dan mengarsipkan semua disain, motif dan produk yang dihasilkan. Hasil pelatihan manajemen seperti Gambar 1.
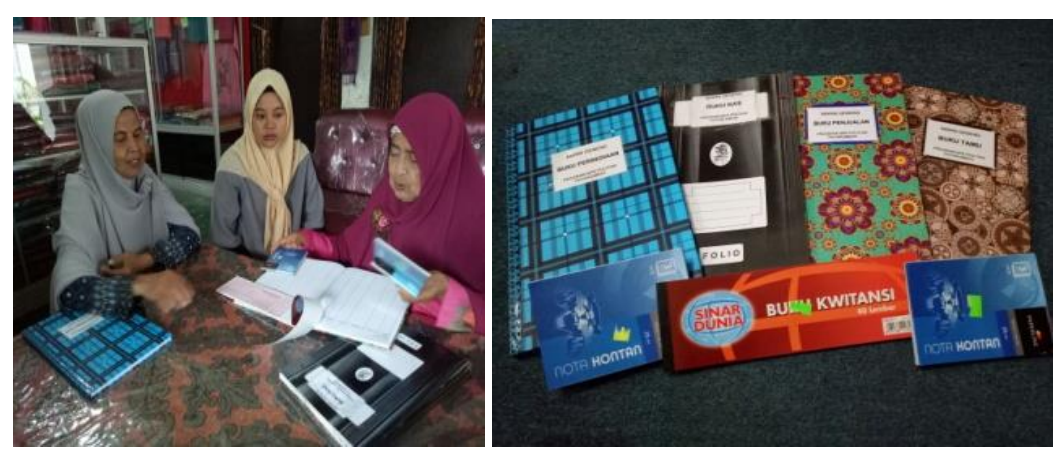

Gambar 1. Pelatihan/Worshop Manajemen

\section{Pelatihan pencelupan alami dengan bahan perwana dari alam}

Selama ini UKM mitra menggunakan benang dari pewarnana kimia, untuk mempersiapkan UKM dengan produk pasar ekspor maka diperlukan bahan benang dari pencelupan alami. Pasar ekspor menghendaki warna-warna natural. Warna natural hanya di peroleh dari bahan yang pewarnanya dari alam seperti daun gambir, kulit manggis dan lain-lain. Hasil dari benang pencelupan alami dihasilkan produk yang berwarna natural dengan bahan katun yang lebih dingin dan enak di pakai. Produk dari hasil pencelupan alami ini seperi Gambar 2. 


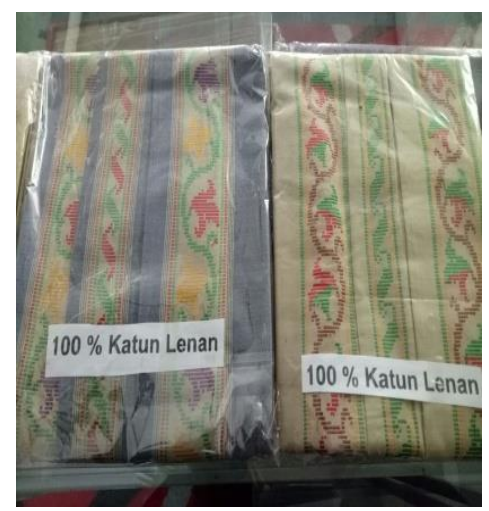

Gambar 2. Produk dari hasil pencelupan alami

\section{Pengembangan Motif}

Dalam rangka menambah varian motif dilakukan pelatihan dengan membawa UKM Mitra ke produsen tenun yang lebih maju dan banyak produksinya di Silungkang. Hasil penelitian ini UKM menghasilkan motif yang lebih menarik dan bunga tabur yang lebih dekat jaraknya dan ukuran kotif bunga tabur juga di perbesar. Seperti disajikan pada pada Gambar 3.

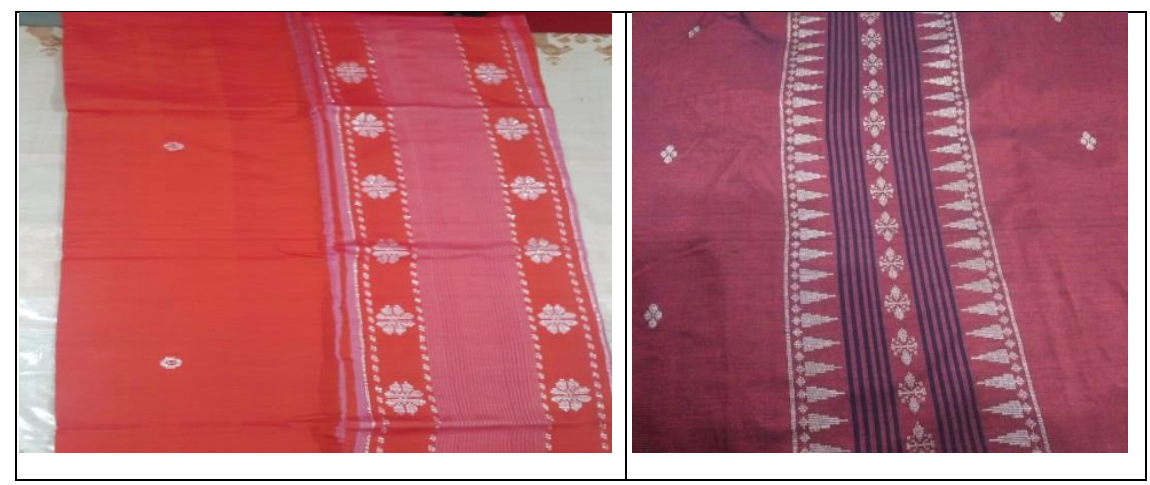

Gambar 3. Desain motif sebelum dan sesudah pelitahan

\section{Promosi}

Dalam rangka memajukan UKM mitra tim IbPE memberikan tanda penunjukkan arah lokasi sehingga konsumen mudah mengetahui lokasi Mitra. Tim IbPE memberikan penunjuk arah untuk kedua UKM, yang dipasang pada jalan raya utama dari Kota Payakumbuh ke kecamatan Guguak. Arah penunjuk jalan kedua arah jalan masuk dari jalan utama ke lokasi UKM mitra, dapat dilihat dari Gambar 4.

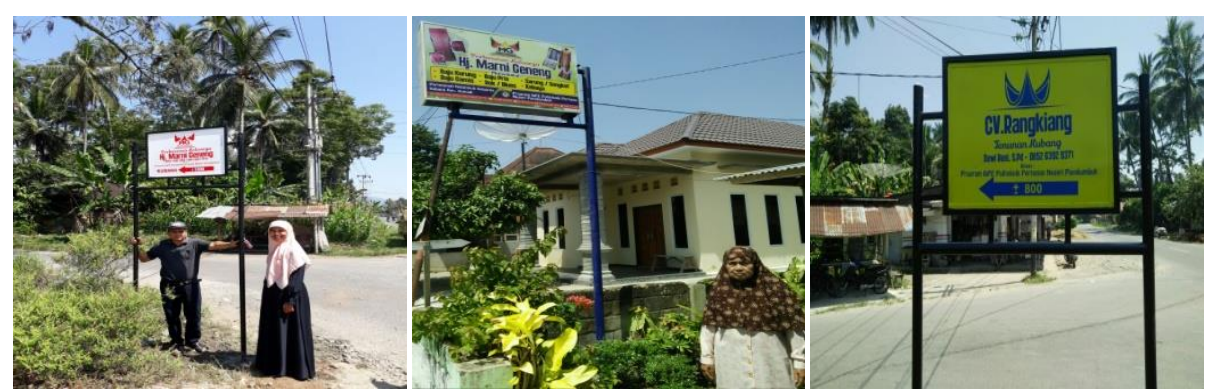

Gambar 4. Pemasangan arah penunjuk jalan kelokasi 
Selain itu tim IbPE juga melengkapi produk dengan memberikan kemasan ke UKM mitra, yang selama ini UKM belum mempunyai kemasan. Hasil dari pemberian kemasan ini UKM mitra sudah dikenal produknya. Sekarang untuk pemsaran sudah memasuk wilayah Sumatera seperti Aceh, Sumatera Utara, Sumatera Selatan, Riau dan Pakan Baru. Kemasan dari masingmasing UKM seperti Gambar 5.
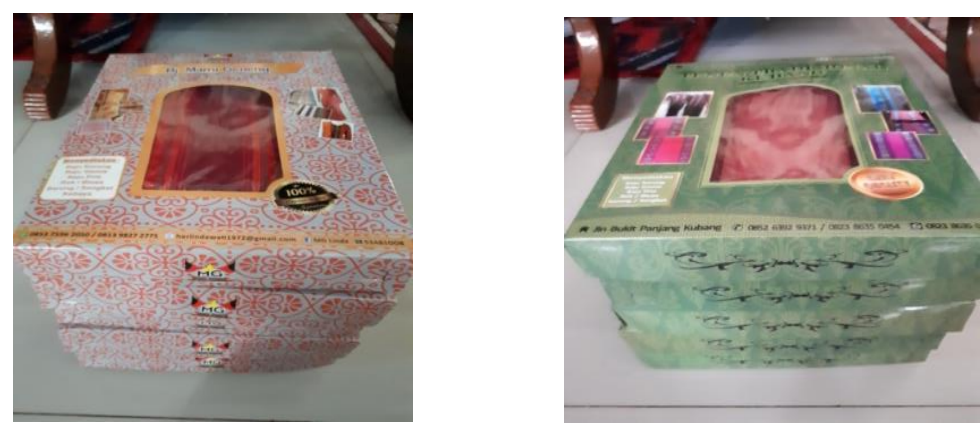

\section{Gambar 5. Kemasan UKM I dan UKM II}

\section{KESIMPULAN}

Kesimpulan yang diperoleh :

1. Ceramah, diskusi dan pendampingan yang diberikan ke UKM I dan UKM II memotivasi UKM untuk lebih maju.

2. Pelatihan pengelolaan administrasi UKM telah membuat kearsipan UKM tertata dengan rapi.

\section{DAFTAR PUSTAKA}

Elida,M., Novita, A,S, Elviati.2015. Laporan IbPE Pengembangan Usaha Rendang Padang Berpotensi Ekspor di Kota Payakumbuh Sumatera Barat. Dibiayai oleh Direkturat Penelitian dan Pengabdian Kepada Masyarakat. Direkturat Jenderal Pendidikan Tinggi. Kementerian Pendidikan dan Kebudayaan, Sesuai dengan Surat Perjanjian Penugasan Program Pengabdian Ipteks bagi Produk Ekspor (IbPE) Lanjutan Batch I. Nomor : 095/SP2H/PPM/DIT. Litabmas /II/3015. Tanggal 5 Februari 2015.

Kartiwa, Suwarti. 1998. Kain Songket Indonesia. Jakarta. Djambatan

Saputra, R. 2015. Budaya Minang, Kesenaian Minang, Tradisi Minang. Diakses www.ranahminang.info/2015/04/songket minang.html

Yulutrip.2014. Pewarna alami untuk tekstil. Blogspot.com.diakses tanggal 15/5/2014. 21 html. 